\title{
Contextual Effect of Place of Birth Delivery on Depression in Karanganyar, Central Java
}

\author{
Ahadyah Miftahul Jannah'), Uki Retno Budihastuti²), Bhisma Murti') \\ 1)Masters Program in Public Health, Universitas Sebelas Maret \\ 2)Department of Obstetrics and Gynecology, Dr. Moewardi Hospital, Surakarta
}

\begin{abstract}
Background: Postpartum depression is a common mental health problem that usually occurs in women after childbirth. According to WHO, there are 377 million people in depression worldwide. In Indonesia, the prevalence of depression sufferers is $3.7 \%$, and those who experience anxiety are 3.3\%. Postpartum depression that is not immediately treated can cause an impact in nursing, namely communication and response is reduced, the existence of negative interactions, the existence of hostility, the existence of impaired competence. This study aimed to analyze the determinants of postpartum depression at the individual level and the contextual effect of place of birth delivery.

Subjects and Method: This was a cross sectional study conducted in Karanganyar, Central Java, from November to December 2018. A sample of 200 postpartum mothers was selected by random sampling. The dependent variable was postpartum depression. The independent variables were stress level, work, income, education, pregnancy status, parity, coping strategy, and labor complication, husband support. Data on depression were measured by the Edinburgh Postnatal Depression Scale (EPDS). Data on stress were measured by Depression Anxiety Stress Scale 42 (DASS 42). Data on coping mechanism were measured by Brief Cope (Coping Orientation for Problem Experiences). The other data were collected by questionnaire and analyzed by a multilevel logistic regression.

Results: Postpartum depression was influenced by husband support $(\mathrm{b}=-2.42 ; 95 \% \mathrm{CI}=-4.73$ to o.12; $\mathrm{p}=0.039$ ), employment $(\mathrm{b}=-3.43 ; 95 \% \mathrm{CI}=-5.51$ to $-1.35 ; \mathrm{p}<0.001)$, income $(\mathrm{b}=-3.32 ; 95 \%$ $\mathrm{CI}=-6.18$ to $-0.46 ; \mathrm{p}=0.023)$, education $(\mathrm{b}=-2.69 ; 95 \% \mathrm{CI}=-4.83$ to $-0.55 ; \mathrm{p}=0.014)$, pregnancy status $(b=-3.16 ; 95 \% \mathrm{CI}=-5.79$ to $-0.54 ; \mathrm{p}=0.018)$, parity $(\mathrm{b}=-2.92 ; 95 \% \mathrm{CI}=-5.14$ to $-0.71 ; \mathrm{p}=$ o.010), coping strategies $(b=-2.38 ; 95 \% \mathrm{CI}=-4.46$ to $-0.21 ; \mathrm{p}=0.032)$, complication $(\mathrm{b}=3.39 ; 95 \%$ $\mathrm{CI}=0.79$ to $5.98 ; \mathrm{p}=0.011)$, and stress level $(\mathrm{b}=2.68 ; 95 \% \mathrm{CI}=0.35$ to $5.12 ; \mathrm{p}=0.024)$. There was a contextual effect of place of birth delivery on postpartum depression (ICC $=20.15 \%)$.

Conclusions: Postpartum depression is influenced by husband support, employment, income, education, pregnancy status, parity, coping strategies, complication, and stress level. There is a contextual effect of place of birth delivery on postpartum depression.
\end{abstract}

Keywords: postpartum mother, depression, stress, coping strategy

\section{Correspondence:}

Ahadyah Miftahul Jannah. Masters Program in Public Health, Universitas Sebelas Maret, Surakarta. Jl. Ir. Sutami No. 36 A, 57126, Surakarta, Central Java. Email: ahadyahmj@gmail.com.

Mobile: +6281228349874 .

\section{BACKGROUND}

Postpartum depression is a mild mental disorder in a woman after giving birth until the 6 th week. The clinical symptoms are a depressed mood, almost all interest in activity decreases, reduced or excessive sleep patterns, significant changes in weight loss or weight gain, under development, energy decreases, feels himself worthless and guilty, insecure, concentration decreases, and there is a sense of desire to commit suicide (Schaffir et al., 2018). In postpartum, maternal psychological health is a problem that needs to be taken into account to 
prevent postpartum maternal illness which greatly affects children, their families and social and economic conditions (Chang et al., 2016).

The number of depressed patients worldwide is 377 million. Of that nearly half are residents living in the Southeast Asia region, which is $27 \%$ and the West Pacific is $\mathbf{2 1 \%}$. Whereas in only Indonesia, the prevalence of depression sufferers is $3.7 \%$, and those who experience anxiety are $3.3 \%$ (WHO, 2017).

Postpartum depression also affects women amounting to $10 \%$ to $15 \%$ in countries with high resources. In developing countries, the prevalence of postpartum depression is quite high, namely India 23\%, Pakistan 44\%, Vietnam 33\%, except in Nepal the prevalence is only $4.9-19.4 \%$ (Bhusan and Bhandari, 2018). Economic conditions also greatly affect postpartum mental disorders, namely major depression, and anxiety (Chang et al., 2016).

Factors associated with postpartum depression include low socio-economic, employment, low income, had experienced depression before, low education, low social support from both the husband, or from a large family, mother age that is too young or too old, unwanted pregnancy, domestic violence (Ram \& Bhandari, 2018), factor of child birth due to unwanted sex or baby born experience complications, maternal medical history, and maternal place of birth (Pham et al. 2017).

Postpartum maternal psychological health is a problem that needs to be considered to make prevention to avoid the burden of pain in postpartum mothers which greatly affects children, their families and social and economic (Chang et al., 2016). Postpartum depression risk factors are a history of using alcoholic beverages, complications suffered during pregnancy, marriages that are not good either forced or have many problems in the household, babies born are being treated intensively for certain reasons, have experienced history previous depression and low social support (Bard, 2018).

The measure of postpartum depression factors is a factor of sociodemography, the existence of a medical history of the mother herself, the presence of psychic history in the mother and the postpartum mother's family, the presence or absence of complications in this pregnancy, a bad experience in hospitalization, babies born today, postpartum experiences when home visits (Pham et al, 2017).

Postpartum depression that is not immediately treated can cause an impact in nursing, namely communication and response is reduced, the existence of negative interactions, the existence of hostility, the existence of impaired competence. While the impact on children is disruption of the breastfeeding process, disturbed sleep patterns, poor health of children, lack of introduction of early foods, poor nutrition of children and lack of stimulation in children (Farías-Antúnezet al., 2018).

\section{SUBJET AND METHOD \\ 1. Study Design \\ This study employs a cross sectional research design. The study was conducted in Karanganyar Regency from November to December 2018. The study was conducted in 20 places of delivery services. This study was conducted in 10 Independent Practice Midwives (BPM), 5 Private Clinics, and 5 Health Centers.}

\section{Population and Samples}

In this study, the total population were all postpartum mothers who gave birth at the health care center in the Karanganyar region from November to December 2018. The samples were selected using a random sampling technique to select postpartum 
mothers and health care services in the Karanganyar area. The subjects used were 200 subjects from 10 subjects at each level 2 unit (health service center).

\section{Study Variables}

The dependent variable is postpartum depression. The independent variables were husband support, stress, work, income, education, pregnancy status, parity, coping strategies, and labor complication.

\section{Operational Definition of Variables}

Husband support is a mental spirit that is obtained from the husband. Stress level is the level of someone experiencing mental stress. Job is someone's activity in daily life to earn income.

Education is the level of someone taking knowledge in a formal place that gets recognition with a diploma. Pregnancy status is a result of conception where the couple does not want to have children from the results of the conception.

Parity is the number of births of a child either dead or alive from a woman. Coping strategy is someone's effort to deal with the stress that occurs on him.

Complication of labor is a complication in the mother's labor process that endangers the safety of the mother and the fetus or both. The measurement scale in the independent variable uses a continuous scale, because for the needs of data analysis, it is converted into a dichotomous.

Postpartum depression is a state of mood disorder in a woman after childbirth characterized by anxiety, anxiety, fatigue, feeling helpless, inadequate, and feeling worthless.

\section{Study Instrument}

Data collection techniques were in the forms of primary data and secondary data. Primary data were obtained using questionnaires filled in by the subject of the study. Secondary data were obtained from the Karanganyar District Health Office in the form of postpartum mothers in Karanganyar Regency. The instruments used were questionnaires and Edinburgh Postnatal Depression Scale (EPDS).

\section{Data Analysis}

Univariate analysis was performed to see the frequency distribution and characterristics of the study subjects, while bivariate analysis was performed using the chisquare test and calculation of the odds ratio (OR) with a 95\% confidence level (CI) to study the relationship between wasting events and independent variables. Multivariate analysis was performed using logistic regression through a multilevel analysis as indicated by the value of Intra Class Corelation (ICC).

\section{Research Ethics}

Research ethics include informed consent, anonymity, confidentiality and ethical clearance. Ethical clearance in this study was carried out at Dr. Moewardi Surakarta. And declared worthy of ethics based on decree number: 324/UN27.6/KEPK/ 2018.

\section{RESULTS}

\section{Sample Characteristics}

Table 1 showed maternal age characteristic. Table 1 showed that mothers aged 20-35 years were 136 (68.0\%).

Table 1. Sample Characteristics

\begin{tabular}{lcc}
\hline Characteristics & n & \% \\
\hline Maternal Age & & \\
< 20 years & 26 & 13.0 \\
20 - 35 years & 136 & 68.0 \\
$>35$ years & 38 & 19.0 \\
\hline
\end{tabular}

\section{Univariate Analysis}

Table 2 showed the results of univariate analysis. Table 2 showed that the majority of sample received strong husband support (22.5\%), $73.0 \%$ working at home, $79.0 \%$ had high family income, $70.5 \%$ had high education, $78.5 \%$ multiparity, $81.0 \%$ had good coping strategy, $79.5 \%$ did not have 
complication, and $81.5 \%$ did not experience

Table 2. Univariate analysis

\begin{tabular}{|c|c|c|}
\hline Independent Variables & $\mathbf{N}$ & \% \\
\hline \multicolumn{3}{|l|}{ Husband Support } \\
\hline Strong ( $\geq$ mean) & 155 & 22.5 \\
\hline Weak $(<$ mean $)$ & 45 & 77.5 \\
\hline \multicolumn{3}{|l|}{ Occupation } \\
\hline Housewife & 146 & 73.0 \\
\hline Labor & 20 & 10.0 \\
\hline Employee & 28 & 14.0 \\
\hline Civil Servant & 6 & 3.0 \\
\hline \multicolumn{3}{|l|}{ Income } \\
\hline$<\operatorname{Rp} 1,696,000$ & 42 & 21.0 \\
\hline$\geq \operatorname{Rp} 1,696,000$ & 158 & 79.0 \\
\hline \multicolumn{3}{|l|}{ Education } \\
\hline Primary school & 12 & 6.0 \\
\hline Junior high school & 32 & 16.0 \\
\hline Senior high school & 144 & 70.5 \\
\hline Diploma & 5 & 2.5 \\
\hline Bachelor & 10 & 5.0 \\
\hline \multicolumn{3}{|l|}{ Pregnancy Status } \\
\hline Wanted pregnancy & 155 & 77.5 \\
\hline Unwanted pregnancy & 45 & 22.5 \\
\hline \multicolumn{3}{|l|}{ Parity } \\
\hline Primipara & 43 & 21.5 \\
\hline Multipara & 157 & 78.5 \\
\hline \multicolumn{3}{|l|}{ Coping Strategy } \\
\hline Do & 162 & 19.0 \\
\hline Didn’t do & 38 & 81.0 \\
\hline \multicolumn{3}{|l|}{ Complication } \\
\hline With difficulty & 41 & 20.5 \\
\hline No difficulty & 159 & 79.5 \\
\hline \multicolumn{3}{|l|}{ Stress Level } \\
\hline Stress & 37 & 18.5 \\
\hline Not stress & 163 & 81.5 \\
\hline
\end{tabular}

\section{Bivariate Analysis}

Table 3 showed the results of bivariate analysis. Table 3 showed that husband support $(\mathrm{OR}=7.85 ; 95 \% \mathrm{CI}=3.71$ to 16.44 ; $<0.001)$, stress $(\mathrm{OR}=4.68 ; 95 \% \mathrm{CI}=2.19$ to 9.97; $\mathrm{p}<0.001)$, occupation $(\mathrm{OR}=17.36$; 95\% $\mathrm{CI}=7.92$ to $38.05 ; \mathrm{p}<0.001)$, income $(\mathrm{OR}=5.33 ; 95 \% \mathrm{CI}=2.56$ to $11.11 ; \mathrm{p}$ $<0.001)$, education $(\mathrm{OR}=8.35 ; 95 \% \mathrm{CI}=$ 3.96 to $17.61 ; \mathrm{p}<0.001)$, unwanted pregnancy $(\mathrm{OR}=9.06 ; 95 \% \mathrm{CI}=4.29$ to 19.15 ; $\mathrm{p}<0.001$ ), primiparous (OR 3.83; 95\% CI= 1.86 to $7.90 ; \mathrm{p}<0.001)$, poor coping strategy $(\mathrm{OR}=5.09 ; 95 \% \mathrm{CI}=2.40$ to $10.81 ; \mathrm{p}$ $<0.001)$, and labor complication (OR= $5.66 ; 95 \% \mathrm{CI}=2.70$ to $11.86 ; \mathrm{p}<0.001)$ increased postpartum depression. stress.

\section{Multilevel Analysis}

Table 4 showed the results of multivariate analysis. Table 4 showed that husband support $(b=-2.06 ; 95 \% \mathrm{CI}=-4.72$ to -0.12 ; $\mathrm{p}=0.039)$, stress $(\mathrm{b}=3.33 ; 95 \% \mathrm{CI}=0.35$ to 5.02; $\mathrm{p}=0.024)$, employment $(\mathrm{b}=-3.23$; 95\% $\mathrm{CI}=-5.51$ to $-1.35 ; \mathrm{p}=0.001)$, income $(\mathrm{b}=-2.28 ; 95 \% \mathrm{CI}=-6.18$ to $-0.46 ; \mathrm{p}=$ o.023), education $(b=-2.46 ; 95 \% \mathrm{CI}=-4.83$ to $-0.55 ; \mathrm{p}=0.014)$, pregnancy status $(\mathrm{b}=-$ $2.36 ; 95 \% \mathrm{CI}=-5.79$ to $-0.54 ; \mathrm{p}=0.018)$, parity $(b=-2.59 ; 95 \% \mathrm{CI}=-5.14$ to $-0.71 ; \mathrm{p}=$ o.010), coping strategy $(b=-2.15 ; 95 \% \mathrm{CI}=-$ 4.56 to $-0.21 ; \mathrm{p}=0.032$ ), and labor complication $(b=2.56 ; 95 \% \mathrm{CI}=0.79$ to $5.98 ; \mathrm{p}=$ o.011) were associated with postpartum depression. 
Journal of Maternal and Child Health, 2019, 4(3): 212-221

https://doi.org/10.26911/thejmch.2019.04.03.08

Table 3. Bivariate Analysis

\begin{tabular}{|c|c|c|c|c|c|c|c|c|}
\hline \multirow{3}{*}{ Independent Variable } & \multicolumn{4}{|c|}{$\begin{array}{l}\text { Postpartum } \\
\text { Depression }\end{array}$} & \multirow{3}{*}{$\mathbf{O R}$} & \multicolumn{2}{|c|}{ CI 95\% } & \multirow{3}{*}{$\mathbf{p}$} \\
\hline & \multicolumn{2}{|c|}{ Yes } & \multicolumn{2}{|c|}{ No } & & \multirow{2}{*}{$\begin{array}{c}\text { Lower } \\
\text { Limit }\end{array}$} & \multirow{2}{*}{$\begin{array}{l}\text { Upper } \\
\text { Limit }\end{array}$} & \\
\hline & $\mathbf{n}$ & $\%$ & $\mathbf{n}$ & $\%$ & & & & \\
\hline \multicolumn{9}{|l|}{ Husband support } \\
\hline Strong ( $\geq$ mean) & 23 & 46.9 & 132 & 87.4 & 7.85 & 3.71 & 16.44 & $<0.001$ \\
\hline Weak $(<$ mean $)$ & 26 & 53.1 & 19 & 12.6 & & & & \\
\hline \multicolumn{9}{|l|}{ Employment } \\
\hline Employed & 14 & 9.6 & 19 & 35.2 & 17.36 & 7.92 & 38.05 & $<0.001$ \\
\hline Unemployed & 35 & 64.8 & 132 & 90.4 & & & & \\
\hline \multicolumn{9}{|l|}{ Income } \\
\hline$<\operatorname{Rp} 1,696,000$ & 22 & 52.4 & 20 & 47.6 & $5 \cdot 33$ & 2.56 & 11.11 & $<0.001$ \\
\hline$\geq \operatorname{Rp} 1,696,000$ & 27 & 55.1 & 131 & 82.9 & & & & \\
\hline \multicolumn{9}{|l|}{ Education } \\
\hline$\geq$ Senior high school & 23 & $14 \cdot 7$ & 133 & $85 \cdot 3$ & 8.35 & 3.96 & 17.61 & $<0.001$ \\
\hline$<$ Senior high school & 26 & 59.1 & 18 & 40.9 & & & & \\
\hline \multicolumn{9}{|l|}{ Pregnancy status } \\
\hline Wanted pregnancy & 22 & 14.2 & 133 & 85.8 & 9.06 & 4.29 & 19.15 & $<0.001$ \\
\hline Unwanted pregnancy & 27 & 60.0 & 18 & 40.0 & & & & \\
\hline \multicolumn{9}{|l|}{ Parity } \\
\hline Primiparity & 20 & 46.5 & 23 & 53.5 & 3.83 & 1.86 & 7.90 & $<0.001$ \\
\hline Multiparity & 29 & 18.5 & 128 & 81.5 & & & & \\
\hline \multicolumn{9}{|l|}{ Coping strategy } \\
\hline Yes & 29 & 17.9 & 133 & 82.1 & 5.09 & 2.40 & 10.81 & $<0.001$ \\
\hline No & 20 & 52.6 & 18 & 47.4 & & & & \\
\hline \multicolumn{9}{|l|}{ Complication } \\
\hline Yes & 22 & 53.7 & 19 & 46.3 & 5.66 & 2.70 & 11.86 & $<0.001$ \\
\hline No & 27 & 17.0 & 132 & 83.0 & & & & \\
\hline \multicolumn{9}{|l|}{ Stress } \\
\hline Stress & 19 & 51.4 & 18 & 48.6 & 4.68 & 2.19 & 9.97 & $<0.001$ \\
\hline Not stres & 30 & 18.4 & 133 & 81.6 & & & & \\
\hline
\end{tabular}

Table 4. The Result of Multilevel Analysis

\begin{tabular}{|c|c|c|c|c|}
\hline \multirow{2}{*}{ Independent Variables } & \multirow{2}{*}{ b } & \multicolumn{2}{|c|}{ CI 95\% } & \multirow{2}{*}{$\mathbf{p}$} \\
\hline & & Lower Limit & Upper Limit & \\
\hline \multicolumn{5}{|l|}{ Fixed Effect } \\
\hline Husband support ( $\geq$ mean) & -2.06 & -4.72 & -0.12 & 0.039 \\
\hline Employment & -3.23 & $-5 \cdot 51$ & -1.35 & 0.001 \\
\hline Income $\geq \operatorname{Rp~1,696,000~}$ & -2.28 & -6.18 & -0.46 & 0.023 \\
\hline Education ( $\geq$ senior high school) & -2.46 & -4.83 & -0.55 & 0.014 \\
\hline Pregnancy status & -2.36 & $-5 \cdot 79$ & -0.54 & 0.018 \\
\hline Parity & -2.59 & -5.14 & -0.71 & 0.010 \\
\hline Coping strategy & -2.15 & -4.56 & -0.21 & 0.032 \\
\hline Complication & 2.56 & 0.79 & $5 \cdot 98$ & 0.011 \\
\hline Stress level & $3 \cdot 33$ & 0.35 & 5.02 & 0.024 \\
\hline \multicolumn{5}{|l|}{ Random Effect } \\
\hline \multicolumn{5}{|l|}{$\mathrm{N}$ observation $=200$} \\
\hline \multicolumn{5}{|l|}{$\mathrm{N}$ group $=20$} \\
\hline \multicolumn{5}{|l|}{ Log likelihood= -27.04 } \\
\hline$p=0.042$ & & & & \\
\hline $\mathrm{ICC}=20.15 \%$ & & & & \\
\hline
\end{tabular}




\section{DISCUSSIONS \\ 1. The effect of husband support on postpartum depression}

The result of this study showed that there was a significant effect of husbands support on postpartum depression $(b=-2.06 ; 95 \%$ $\mathrm{CI}=-4.73$ to $-0.12 ; \mathrm{p}=0.039)$. Postpartum mothers who have strong husband support reduce the risk of postpartum depression by 2.06 higher compared to postpartum mothers who have low husband support.

The result of this study was supported by a study by Chang (2018). A high level of social support from husbands, families, friends, and people around them would increase psychological welfare. Support given by husbands to wives during postpartum would foster self-confidence in mothers in their ability to care for their infants (Ichan, 2015 cite Purwati and Kustiningsih, 2017).

Mothers who got social support from their families would be happy to see their babies and not easily tired in caring for their infants (Purwati and Kustiningsih, 2017). From the beginning of pregnancy to the postpartum period in the mother, family support was very meaningful, because with family support, especially partners would make mothers happy and comfortable and prevent the occurrence of depression (Rini \& Kumala, 2016).

\section{The effect of stress on postpartum depression}

The result of this study showed that there was a significant effect of stress level on postpartum depression $(b=3.33 ; 95 \% \mathrm{CI}=$ 0.35 to $5.92 ; \mathrm{p}<0.001$ ).

Postpartum mothers who have low stress levels reduce the risk of postpartum depression by 3.33 units compared to postpartum mothers who have high stress levels.

Various psychological reactions to postpartum women were from the mothers, husband, household and surrounding environment. This psychological reaction would influence the maternal attitude, behavior, and emotional level. When mothers were less able to conduct effective control of these psychological reactions, then this psychological problem was called stress. Stress in postpartum mothers often occurred in almost all mothers who have done labor. Postpartum stress occurred on the first day until the 1oth day after labor which was characterized by feelings of loneliness, anxiety, confusion, fatigue, forgetfulness, and unable to sleep (Ningrum, 2017).

\section{The effect of employment on post- partum depression}

The result of this study showed that there was a significant effect of employment on postpartum depression $(\mathrm{b}=-3.32 ; 95 \% \mathrm{CI}=$ -5.51 to -1.36 ; $\mathrm{p}<0.001$ ).

Unemployed mother reduced the risk of postpartum depression by 3.32 units compared to postpartum mothers who have a job.

Hariyono et al. (2016) stated that mental stress occurred due to many aspects of work. The occurrence of stress among working woman depend on her respond to work, work rules and the work environment. The stress factor was not only caused by one reason in work, but also included shift work, overtime, the role of a worker on maternity leave, labor, and so on. The stress experienced by female workers would cause postpartum depression. Because the majority of women were working, the work environment has a major impact on being a stressor for women which caused mental stress as well as the many demands of assignments, lack of social support in work (supervisors and managers support) and difficult communication between friends and superiors. 


\section{The effect of income on post- partum depression}

The result of this study showed that there was a significant effect of income on postpartum depression $(\mathrm{b}=-2.28 ; 95 \% \mathrm{CI}=-$ 6.18 to $-0.46 ; \mathrm{p}=0.023)$.

Postpartum mothers who have high income reduce the risk of postpartum depression by 2.28 units compared to postpartum mothers who have low income.

This was in line with a study by Gelaye et al. (2016). Low-income countries affected 1 in 4 women to experience postpartum depression, WHO recommend to provide primary health care to low-income mothers who were at risk of postpartum depression. Depression that often occurred in postpartum mothers in low and middle income countries was very likely to occur, for example, mothers who have low income have difficulty to buy food, disruption of interaction between mother and child, living conditions in densely populated communities in low-income countries, hardness between individuals (Herba et al., 2016).

\section{The effect of education on post- partum depression}

The result of this study showed that there was a significant effect of education on postpartum depression $(\mathrm{b}=-2.46 ; 95 \% \mathrm{CI}=-$ 4.83 to $-0.55 ; \mathrm{p}=0.014$ ).

Postpartum mothers who have high level of education reduce the risk of postpartum depression by 2.46 units compared to postpartum mothers who have low education.

The result of this study was supported by Stepanikova \& Kukla (2017), who stated that women with low level of education would increase the risk of depression after childbirth, low education was a low indicator of a person in terms of socio-economic status. A mother who has low educa- tion would face a difficulty in getting a quality job (Kim \& Dee, 2018).

\section{The effect of pregnancy status on postpartum depression}

The result of this study showed that there was a significant effect of pregnancy status on postpartum depression $(\mathrm{b}=-2.36$; $95 \%$ $\mathrm{CI}=-5.79$ to $-0.54 ; \mathrm{p}=0.015)$.

Postpartum women who wanted their pregnancy reduce the risk of postpartum depression by 2.36 units compared to postpartum mothers who have unwanted pregnancies.

Abbasi et al., (2013) stated that unwanted pregnancy was not planned for lack of mental readiness, lack of support for pregnancy could lead to postpartum depression by two times. However, Asian and Hispanic ethnic populations have almost no depression in their pregnancies, and depression itself has been treated before pregnancy, however, the incidence of postpartum depression in Asia and Hispanic was higher.

\section{The Effect of Parity on Postpartum Depression}

The result of this study showed that there was a significant effect of parity on postpartum depression $(\mathrm{b}=-2.59 ; 95 \% \mathrm{CI}=-$ 5.14 to $-0.71 ; p=0.010$ ).

Postpartum mothers who have multiparous parity reduce the risk of postpartum depression by 2.59 units compared to postpartum mothers who have primiparous parity.

The number of children born whether alive or dead would cause a level of mental stress in the mother. Because the mother was still taking care of her newborn baby and also taking care of the other children, because of this condition, it would cause the mother to feel exhausted, lack of sleep, lack of rest (Badr, 2018). The more the mothers give birth to children and getting older, the lower the health of the mothers 
and they were susceptible to complications during labor (Kerns et al., 2018).

\section{The effect of coping strategy on postpartum depression}

The result of this study showed that there was a significant effect of coping strategy on postpartum depression $(\mathrm{b}=-2.15 ; 95 \% \mathrm{CI}=$ -4.56 to $-0.21 ; \mathrm{p}=0.032)$.

Postpartum mothers who often do coping strategies reduce the risk of postpartum depression by 2.15 units compared to postpartum mothers who have never done coping strategies.

Nasekah (2013), explained thatgood coping strategies that they used in solving problems and feelings that interfere their life and environment. Where the positive impacts shown by the participants were finding the meaning of life and loving their husband and children more, while the negative impact was that the participant lose interest in doing activities and the feeling of regretting the presence of their children so that the children got lack of love. Overcoming depression problems could be done by solving the problems, positive actions and mindset, showing the extent to which a person's anxiety can be overcome. Coping was strongly associated with depression (Marguerite et al., 2017).

\section{The effect of pregnancy complica- tion on postpartum depression}

The result of this study showed that there was a significant effect of pregnancy complication on postpartum depression $(b=$ 2.56; 95\% CI= 0.79 to $5.98 ; \mathrm{p}=0.011$ ).

Postpartum mothers who have no pregnancy complications reduce the risk of postpartum depression by 2.56 times compared to postpartum mothers who have pregnancy complications.

The result of this study was supported by Kettunen et al. (2016), difficult labor was labor that experienced complications in which labor required the some tools to give birth to children either by caesarean section, vacuum or forceps, which can make the body feel hurt and uncomfortable so that the mother experienced stress, therefore, labor complications can be a risk factor to be a predatory factor for postpartum depression.

\section{The effect of place of birth deli- very on postpartum depression}

The result of this study showed that birth delivery place had contextual effect on postpartum depression with $\mathrm{ICC}=\mathbf{2 0 . 1 5 \%}$.

The location of residence with a place of health facilities became the most important consideration in choosing a place of delivery, because labor mostly occurred without the correct timing, even though the date of delivery has been determined since the beginning of pregnancy. Labor also often occurred at night and even early in the morning, so that the distance from home to the place of birth delivery can be considered (Handy, 2015).

Based on the results of the study, it can be concluded that there was a significant effect of husband support, stress, employment, income, education, pregnancy status, parity, coping strategies, and labor complications on postpartum depression. Variations in the place of birth delivery level showed that there was a contextual effect on postpartum depression.

\section{REFERENCES}

Abbasi S, Chuang CH, Dagher R, Zhu J, Kjerulff K (2013). Unintended pregnancy and postpartum depression among first-time mothers. Journal of Women's Health, 22(5), 412-416. https://doi.org/10.1089/jwh.2012.39 26.

Badr LK (2018). Infant behavior and development is the effect of postpartum depression on mother - infant bonding universal?Journal of Infant Beha- 
vior and Development, 51: 15-23. https://doi.org/10.1016/j.infbeh.2018 .02.003.

Chang FW, Lee WY, Liu YP, Yang JJ, Chen SP, Cheng KC, Liu JM (2016). The relationship between economic conditions and postpartum depression in Taiwan: A nationwide populationbased study. Journal of Affective Disorders, 204, 174-179. https://doi.org/10.1016/j.jad.2016.06.43

Farías-Antúnez S, Xavier MO, \& Santos IS. (2018). Effect of maternal postpartum depression on offspring's growth. Journal of Affective Disorders, 228, 143-152. https://doi.org/10.1016/j.jad.2017.12.013.

Gelaye B, Rondon MB, Araya R, Williams MA (2016). Epidemiology of maternal depression, risk factors, and child outcomes in low-income and middleincome countries. The Journal of Lancet Psychiatry, 3(10), 973-982. https://doi.org/10.1016/S22150366(16)30284-X

Hariyono W, Suryani D, Wulandari Y. (2016). Hubungan antara beban kerja, stres kerja dan tingkat konflik dengan kelelahan kerja perawat di Rumah Sakit Islam Yogyakarta PDHI Kota Yogyakarta. Jurnal Kesehatan Masyarakat (Journal of Public Health). 3(3):186-97.

Herba CM, Glover V, Ramchandani PG, Rondon MB (2016). Maternal depression and mental health in early childhood: an examination of underlying mechanisms in low-income and middle-income countries. The Journal of Lancet Psychiatry, 3(10): 983992. https:// doi.org/10. 1016/ S22150366(16)30148-1.

Kerns AJL, Light A, Dalton V, Mcnamara B, Steinauer J, Kupperman M (2018). Patient education and counseling.
Manuscript of decision satisfaction and pregnancy termination https:// doi. org/10.1016/j.pec.2018.06.012

Kettunen P, Koistinen E, Hintikka J (2016). Risk factors and negative life events on postpartum depression and their role in first and recurrent depression, Article Research of Depression Research and Treatment, 6-9. https://doi.org/10.1155/2016/2514317.

Kim Y, Dee V (2018). Sociodemographic and obstetric factors related to symptoms of postpartum depression in hispanic women in Rural California. JOGNN - Journal of Obstetric, Gynecologic,

Laela S, Anna Keliat B, Mustikasari (2018). Thought stopping and supportive therapy can reduce postpartum blues and anxiety parents of premature babies. Journal of Enfermeria Clinica, 28: 126 - 129. https://doi.org/10.1016/S11308621 (18) 30051-2

Marguerite S, Laurent B, Marine A, Tanguy L, Karine B, Pascal A, Xavier Z (2017). Actor-partner interdependence analysis in depressed patient-caregiver dyads: Influence of emotional intelligence and coping strategies on anxiety and depression. Journal of Psychiatry Research, 258: 396-401. https://doi.org/10.1016/j.psychres.2017.08. 082.

Ningrum SP (2017). Faktor-faktor psikologis yang mempengaruhi postpartum blues. Psympathic: Jurnal Ilmiah Psikologi.

Pham D, Cormick G, Amyx MM, Gibbons L, Doty M, Brown A, et al. (2017). Factors associated with postpartum depression in women from low socioeconomic level in Argentina: A hierarchical model approach. Journal of Affective Disorders, 227: 731-738. 
https://doi.org/10.1016/j.jad.2017.11. 091.

Purwati Y, Kustiningsih (2017). Bagaimana menghadapi mood masa nifas. Yogyakarta: CV BUDI UTAMA.

Ram B, Bhandari N (2018). Identifying the factors associated with depressive symptoms among postpartum mothers in Kathmandu, Nepal. International Journal of Nursing Sciences. https://doi.org/10.1016/j.ijnss.2018.o 4.011.

Schaffir J, Kunkler A, Lynch CD, Benedict J, Soma L, Doering A (2018). Association between postpartum physical symptoms and mood. Journal of Psy- chosomatic Research, 107 (February), 33-37. https://doi.org/10.1016/j. jpsychores. 2018. 02. 003 .

Stepanikova I, Kukla L (2017). Is perceived discrimination in pregnancy prospectively linked to postpartum depression? exploring the role of education. Maternal and Child Health Journal, 21(8), 1669-1677. https://doi.org/10.1007/s10995-016-2259-7.

World Health Prganization (WHO).(2013). Maternal and Chld Mental Health. http://www.who.int/mental_health/ maternal-child/en/ (diakses tanggal 6 Oktober 2017). 